\title{
Social value for whom, by whom and when? Managing stakeholder dynamics in a UK megaproject
}

DOI:

10.1680/jmapl.19.00018

\section{Document Version}

Accepted author manuscript

Link to publication record in Manchester Research Explorer

\section{Citation for published version (APA):}

Mulholland, C., Chan, P., Canning, K., \& Ejohwomu, O. (2020). Social value for whom, by whom and when? Managing stakeholder dynamics in a UK megaproject. Proceedings of Institution of Civil Engineers: Management, Procurement and Law, 173(2), 75-86. https://doi.org/10.1680/jmapl.19.00018

\section{Published in:}

Proceedings of Institution of Civil Engineers: Management, Procurement and Law

\section{Citing this paper}

Please note that where the full-text provided on Manchester Research Explorer is the Author Accepted Manuscript or Proof version this may differ from the final Published version. If citing, it is advised that you check and use the publisher's definitive version.

\section{General rights}

Copyright and moral rights for the publications made accessible in the Research Explorer are retained by the authors and/or other copyright owners and it is a condition of accessing publications that users recognise and abide by the legal requirements associated with these rights.

\section{Takedown policy}

If you believe that this document breaches copyright please refer to the University of Manchester's Takedown Procedures [http://man.ac.uk/04Y6Bo] or contact uml.scholarlycommunications@manchester.ac.uk providing relevant details, so we can investigate your claim.

\section{OPEN ACCESS}




\section{Social value for whom, by whom and when? Managing stakeholder dynamics in a megaproject}

Studies of project success have generally recognised the role stakeholder management plays in shaping a collective understanding of value. While these studies have typically focused on new-build, few studies have examined stakeholder management at the end of life of a built asset. This paper draws on a single megaproject case study into social value in nuclear decommissioning and remediation to examine how 'success' or 'failure' in projects is framed, and the implications of stakeholder management in shaping these notions of performance. By tracing historical developments of Dounreay, an experimental nuclear energy site at an advanced stage of decommissioning, it was found that key stakeholders change over time as those most affected by the changing dynamics of the megaprojects come and go, with resulting impacts on the ways conditions for success are framed and social value is defined. Our findings stress the importance of taking a pluralistic and processual view of stakeholders, and demonstrate the need for policy-makers, practitioners and researchers to pay greater attention to fragmentation and integration of stakeholders' interests and influences as they change over time. These dynamics of stakeholder management will in turn challenge preconceived ideas of success that are often framed in the early stages of a project.

Keywords: decommissioning, social impact, (mega)project management, Government, nuclear power, infrastructure planning 


\section{Introduction}

2 Ever since Freeman (1984) argued for the need to think beyond the shareholder to consider

3 the needs of stakeholders, there have been numerous studies that examine stakeholder

4 management practices in project contexts (see e.g. Mok, Shen and Yang, 2015).

5 Consideration of broader stakeholder needs has since challenged the orthodoxy that project

6 success is merely the meeting of such traditional measures as time, cost and quality

7 (Atkinson 1999). There is growing recognition of the tensions that can arise from attempts

8 to meet the short-term 'iron triangle' of project time, cost and quality performance and the

9 capturing of long-term, lasting impacts of projects (Eriksson et al., 2014). Indeed, as Eskerod,

10 Huemann and Ringhofer ( 2015) argued delivering valuable impacts to project stakeholders

11 can be a challenge as they noted that stakeholder disappointment continues to be a

12 common feature of unsuccessful projects.

13 In a recent systematic review of scholarship on project stakeholder management, Mok, Shen

14 and Yang (2015) identified how studies have tended to focus on formalising stakeholder

15 management processes often in small-scale projects and typically focussing on the early

16 planning stage of the project life cycle. Such emphasis has come under critical scrutiny. For

17 example, in finding universal, systematic approaches to managing stakeholders, Engwall

18 (2003) argued that there has been relative neglect in understanding the unique specificities

19 of the institutional context in which projects are situated. Moreover, by focussing mainly on

20 the planning stage of the project life cycle, there is an implicit assumption that project

21 managers can design interventions that satisfy often conflicting needs of a multitude of

22 stakeholders at the front-end of projects; this ignores the reality of stakeholder management

23 as an ongoing process rather than a 'done deal' achieved through planning (Eskerod,

24 Huemann and Savage, 2015; Eskerod and Larsen, 2018). The need to examine stakeholder

25 management as an ever-changing, ongoing process (Friedman and Miles, 2002; Turkulainen 

et al., 2015; Chan, 2016) is further underscored where megaprojects are concerned, a context that has been relatively overlooked in stakeholder management scholarship (Mok, Shen and Yang, 2015).

In this paper, we address these deficiencies by drawing on case study research into a megaproject in nuclear decommissioning to examine how stakeholder management - as an ongoing process - can have significant consequences for the ways in which project 'success' and 'failure' is defined. We situate this case study within the contemporary and growing concern over delivering social value in the megaproject context. In the UK, for instance, the introduction of the Public Services (Social Value) Act in 2012 mandates that the provision of public goods and services, including the delivery of public-sector projects, must consider how the work "might improve the economic, social and environmental well-being of the relevant area" (p. 2, Public Services (Social Value) Act 2012). While delivering social value along this triple bottom line seems reasonable, defining what this means is less straightforward since there is no accepted definition of what social value means (see Nakamba et al. 2017). Furthermore, growing interest in social value in construction (Cartigny \& Lord 2017; Raidén et al. 2019; Daniel \& Pasquire 2018) has often focussed on client perspectives in the procurement of construction projects (Cartigny \& Lord 2018; Awuzie \& McDermott 2016; Loosemore 2015) with relative less attention paid to a wider range of stakeholders affected by construction. Thus, our case study context of examining the dynamics of stakeholder management in Dounreay, an experimental nuclear facility that is at an advanced stage of decommissioning, is unique; while much research, even on mega construction projects, is on new-built, the context in this study is on nuclear decommissioning and remediation (Mulholland et al. 2019; Invernizzi et al. 2017). Thus, we also contribute to the literature by broadening out beyond (front-end) planning to consider the dynamics of stakeholder management during the end-of-life stage of the asset/project life cycle. 
51 In what follows, we first review the literature on related fields of stakeholder management in

52 (mega-)project studies. We then explain the case study methodology before reporting and

53 discussing the findings of the implications of stakeholder management dynamics and the

54 notions of project 'success' or 'failure'.

\section{Stakeholder management: a planned or emergent process?}

56 Good governance of and engagement with stakeholders, with defined roles and

57 responsibilities and dedicated communication channels, have long been attributed as a key

58 condition of megaproject success (see Caldas and Gupta, 2016). To satisfy the needs of

59 project stakeholders, scholars have developed frameworks to characterise stakeholders

60 based on their relative position within or beyond the project organisation and their

61 respective influence and interest on project outcomes (e.g. Savage et al. 1991; Karlsen 2002;

62 Olander 2007; Ackermann \& Eden 2011). These frameworks, often depicted as two-by-two

63 matrix of power and predictability of outcomes, are used to visually group and prioritise

64 stakeholders based on their power, legitimacy and urgency (see Mitchell et al, 1997), so that

65 the management of stakeholder expectations can be more effectively planned and managed

66 so that surprises and disruption to projects can be minimised. Others have developed more

67 nuanced, graphical methods to help project managers visualise the scale and scope of a

68 stakeholder's influence, the extent to which a stakeholder is more or less powerful, and the

69 depth of impacts to help identify where a potential stakeholder is coming from and

70 anticipate what is in it for the stakeholder (e.g. Bourne and Walker, 2005; 2006; Walker et

71 al., 2008). These tools are intended to guide project managers when seeking the

72 cooperation of, collaboration with or even containing stakeholders early on in the planning

73 phase of a project, which in turn creates the social license for a project to go ahead

74 (Aaltonen and Kujala, 2010; Aaltonen et al. 2015; Sánchez 2015). 
75 These models have however come under critical scrutiny in recent times. For example, Davis

$76(2014 ; 2016)$ noted that how failure or success is viewed depends on the point in time when

77 a project's performance is measured. Shenhar and Holzmann (2017) re-evaluated the

78 success and failure of 14 megaprojects to show how 'failure' or 'success' can change

79 depending on whether one focussed on the immediate utility at the point of project delivery

80 or whether one considered the longer-term societal impacts that the project yielded.

81 Shenhar and Holzmann (2017) added that while alignment of all stakeholders to a shared

82 goal is desirable, the reality requires constant adaptation to complexity. This is especially

83 true in the megaproject context. For instance, in the nuclear energy sector, Locatelli et al.

84 (2014) reinforce this need for ongoing flexibility by arguing for looking beyond the

85 attainment of technical success to ensure that project teams build and sustain community

86 and political support. So while scholars have long called for a dynamic approach to engaging

87 with stakeholders (e.g. Bourne and Walker, 2006; Walker et al., 2008), prevailing frameworks

88 tend to focus on the identification of stakeholders and their needs and influences at a point

89 in time rather than to account for how these change over time (Jepsen and Eskerod, 2009;

90 Aaltonen and Kujala, 2010, and; Eskerod, Huemann and Savage, 2015). Thus, in line with

91 these recent calls to take a more processual view of stakeholder management, this study

92 focuses on the process of sensemaking as the identification and influence of who and what

93 matters changes over time.

94 Making sense of social value in megaprojects

95 Turning our attention to social value, there are also parallels that can be drawn between the

96 brief review of studies on managing stakeholders in (mega-)projects above and

97 developments in thinking about social value creation. Early scholarship on social value has

98 often focussed on the development of measurement frameworks with the identification of

99 stakeholders and their needs central to many. In the UK, examples of measurement 
100 frameworks include the Social Value Evidencing Toolkit (SVET) developed to manage the

101 social value reporting processes for Highways England (Daniel \& Pasquire 2017); applying

102 ecosystem services thinking to geographic information systems (GIS) Mapping to determine

103 the perceived use value of places, and; using a Social Values for Ecosystem Services (SoIVES)

104 tool to capture the benefits of the natural environment on human wellbeing (Sherrouse et al.

105 2011). These frameworks are predicated on the assumption that engagement with

106 stakeholders is key in collecting information about what matters and assessing the social

107 value impacts created by projects.

108 Of the many frameworks available to capture social value, the Social Return on Investment

109 (SROI) methodology that attempts to quantify the monetary value of social investments is

110 the most commonly adopted approach. It has been used to underpin common tools such as

111 Social Profit Calculator and Social Value Portal (REF), with the latter creating the National

112 TOMS (Themes, Outcomes, Measures) which is being adopted slowly within the built

113 environment (REF). The SROI methodology developed in 2001 by the Roberts Enterprise

114 Development Fund (2001), a California-based employment social enterprise and refined by

115 the New Economics Foundation (NEF), seeks to produce a replicable, reliable methodology to

116 facilitate objective comparisons of social outcomes of projects. This SROI process relies

117 heavily on the use of agreed proxies (for example the Housing Associations' Charitable Trust

118 (HACT) Wellbeing Evaluation approach (Cabinet Office 2015)).

119 Although establishing an objective set of proxy measures can make it easier to compare the

120 social value outcomes across different projects, critics have also identified a number of

121 major shortcomings. For instance, Gair (2005) argued that the emphasis on quantifying

122 social returns of investment obscures the more qualitative aspects that give specificity to the

123 context of these economic and socio-economic measurements. In privileging what is

124 perceived to be objective and quantitative measures, there is also a sense that SROIs 
125 highlight what is universal rather than what matters at a local level. Thus, even though the

126 New Economics Foundation (2007) suggests that stakeholders should be engaged in the

127 process of identifying what gets measured are the 'right' things for stakeholders concerned,

128 power is still implicitly placed with those who are considered "primary stakeholders, people

129 directly involved in the creation of social value, for example, project participants, or

130 employees"(p. 35) as these determine what kinds of data get collected. Thus, there have

131 been calls to move towards a more bottom-up approach of assessing cost-benefits and

132 impacts (Nicholls 2016; Gair 2005). Indeed, as Watson and Whitley (2017: 887) reflected in

133 their application of SROI in a construction project, "the data-crunching stages of the method

134 are far removed from the qualitative focus group data about specific design features".

135 Watson and Whitley (2017) also noted how it is not always possible to measure social value

136 simply by tracking what has changed before and after a design intervention because, and

137 especially in the case of new-built, the stakeholders have not experienced the built

138 environment before the transformation, and so what can only be captured are the

139 experiences of the new environment.

140 Thus, our salient review of social value reflects similar concerns already raised in our critique

141 of scholarship on managing stakeholders in projects in two ways. First, while there is

142 recognition that social value can mean different things to different people, there is a

143 tendency to focus on measuring and presenting social value as monolithic, objective 'truth',

144 in part because of the desire to enable comparisons in an audit society (see Power, 1997;

145 Shore and Wright, 2015). Second, the push towards quantification also means that focus is

146 placed on measuring social value at a moment in time, rather than to examine how social

147 value changes dynamically over time. In the context of megaprojects, tracking the ongoing

148 process of change over time, as opposed to leaving it to the end of the project, is paramount

149 as it is crucial not only to build political and community support for the project but also to

150 sustain that support over time. 
151 Yet, in privileging the measurement and quantification of social value, a crucial step in the

152 process of establishing which aspects of social value matter to those affected by projects is

153 often overlooked; that is, there is a first of all make sense on who the key stakeholders are.

154 But, the question as to who are 'key' stakeholders changes over time. This is especially the 155 case in megaproject contexts. As Clegg et al. (2016) argued, as a project unfolds there is a 156 need to keep making sense of how stakeholders are changing and developing, and how this

157 evolution changes what they value, particularly since there are often complex and divergent

158 needs that change over the long timeframes that characterise megaprojects. Thus, rather

159 than to focus only on the quantitative measure of social value at a particular point in time, it

160 is important to pay greater attention to the unfolding narratives and changing discourses on

161 who and what matters over the project lifecycle (see Kornberger et al. 2006; Aaltonen and

162 Kujala, 2010).

163 Project studies have often been dominated by claims to rationality early on in the project

164 lifecycle (Clegg et al., 2016). For instance, it is typically the case that scholars argue for the

165 need to engage with stakeholders early on in the project lifecycle so that the power and

166 predictability of stakeholders can be mapped out to ensure the success of megaprojects

167 (Zidane et al. 2015; Ninan \& Mahalingam 2017). Yet, this belief downplays the realities of

168 contestation and change, and the role resistance can play to generate productive value in

169 projects (Courpasson et al., 2011). In this paper, we join the growing line of scholarship that

170 emphasises the dynamic process of managing stakeholders and the creation of social value

171 through a single case study of decommissioning an experimental nuclear site in Dounreay in

172 Scotland.

\section{The Decommissioning Case Study}

174 Social impacts of transforming society that could affect the livelihoods of millions of people

175 are a defining characteristic of megaprojects (Flyvbjerg, 2014). The scale of these social 
176 implications means that there is, more than ever, a significant need to engage with

177 stakeholders to define the performance (Mišić and Radujković, 2015) and to account for the

178 socially responsible outcomes of these projects (Ma et al., 2016). With the introduction of

179 the UK Public Services (Social Value) Act in 2012 the public sector needs to demonstrate

180 'social value' as part of any project delivery, and this calls into question as to what 'success' is

181 in terms of a socially valuable project.

182 In this paper, we draw on a case study in the UK nuclear decommissioning sector. The

183 Nuclear Decommissioning Authority (NDA) as a non-departmental public body reporting to

184 the Department for Business, Energy and Industrial Strategy, owns and is responsible for

185 decommissioning 17 nuclear sites in the UK. The programme is estimated to last 120 years,

186 with a projected cost of $£ 120$ billion. Delivering value for taxpayers' money whilst

187 addressing challenging technological and social complexities is therefore a wicked problem

188 that the NDA has to deal with. In this case study, we focus on Dounreay, the site of an

189 experimental nuclear facility constructed in 1955 to house what was then a first-of-a-kind

190 technology known as the 'Fast Breeder' reactor. Now Scotland's largest nuclear clean-up

191 and demolition project, the decommissioning and site remediation work is being contracted

192 since 2012 on a target cost basis to Dounreay Site Restoration Limited (DSRL), one of the site

193 license companies (SLC) directly funded by the NDA.

194 Data Collection and Analysis

195 Our case study of Dounreay was informed by data collection that allowed us to trace how

196 Dounreay, its site and the local community, evolved from the time of its construction to the

197 present day. Documents were collected from a wide range of sources as is common for case

198 studies (Ridder, 2017), including official reports and publicity materials from DSRL and the

199 NDA, web-based information such as blogs and discussion boards, research papers and

200 theses about Dounreay, paraphernalia from local museums and places of interest to piece 
201 together this historical overview, which enabled the reconstruction of how the concept of

202 'social value' was framed over time. 'Social value' was assessed against a typology

203 developed from academic literature, listed in Figure 1. The richness of the documents (circa

204 200) collected with a case study approach (Ridder, 2017) also allowed us to retrospectively

205 see how decisions made in the past had intended and unintended consequences for

206 delivering social value to those living in the area. We were able to investigate how

207 relationships between those working in Dounreay, and more recently DSRL and the NDA, and

208 the local communities changed over time, with resultant implications on perceived social

209 value.

210 INSERT FIGURE 1

211 The historical perspective, along with how 'social value' is perceived in the present day and

212 projected in the future, were also gathered through interviews with key stakeholders

213 representing DSRL and the local community. These interviews $(n=9)$ were chosen through a

214 purposive sampling process through our connections with the NDA and Dounreay Limited

215 using a snowballing process (Ridder, 2017). The interviewees all lived within proximity of

216 Dounreay, representing either a 'community member' or 'working on site' as detailed in

217 Table 2. The interviews were compared with the documentary analysis to enable us to

218 develop corroborated insights into to how notions of 'success' and 'failure' were framed by

219 the actors concerned as they and the framing of 'success' and 'failure' changed over time.

220 Thus, we attempted to follow the actors to capture the past, present and perceptions of the

221 future as conversations around social value changed in Dounreay over time from a cross-

222 sectional study done over the course of 10 days.

223 INSERT TABLE 2 
224 Semi-structured interviews focused on the participants' role and involvement, if any, with

225 the site and its societal value following an interview protocol (Spradley 1979), with the core 226 questions:

- Tell me about your background (professionally and personally)

- What are your views on nuclear decommissioning, remediation and regeneration?

- Have you heard of 'social value'? If not, what do you think it means?

- How does social value link in the work you do in decommissioning or regeneration?

- What do you think is the future of nuclear energy [and decommissioning] in your

The participants were encouraged to talk freely and asked to elaborate on how and why things happened in the ways they did in their interview accounts where appropriate. The interviews were audio-recorded and transcribed verbatim. In addition to the interviews, the

236 first author also observed two private Site Stakeholder Group sub-committee meetings, one

237 focused on socio-economic impacts and one on decisions regarding site-end state, with

238 around 20 community representatives invited to sit on the committee to open dialogue with

239 site representatives. Furthermore, following the ethnographic walking methodology (Evans

240 \& Jones 2011) she also did a number of site visits (see Table 2) to the decommissioning site,

241 local archives, nuclear museum, and heritage museum. Extensive notes were taken (circa

242100 pages) along with photographs $(n=380)$ of the local area to add richness of information

243 about the local context. These notes also allowed the first author to reflect on what was

244 observed and to identify emerging themes (Eisenhardt 1989).

245 The interview transcripts, field notes from observational research and site visits, and 246 documentary analysis were analysed to identify key emerging themes using qualitative data 247 software coding (Braun and Clarke, 2006), which we then compared with themes identified 248 in the stakeholder management and social value literature. In particular, we reflected on 
249 how our analytical categories inform us about who had interest and influence in Dounreay

250 (e.g. Olander 2007), and who were deemed to have power, legitimacy and urgency (Mitchell

251 et al., 1997), paying careful attention to how these changed over time. We also examined

252 how 'success' or 'failure' was talked about and, where possible, identified how these

253 connected with the proxy measures of social value found in the literature, listed in Figure 1.

254 In line with inductive research, our analysis began as soon as our fieldwork began, and the

255 number of interviews in our snowball sampling was deemed sufficient when we reached

256 saturation, i.e. when our analysis was beginning to yield no significantly new insights (Guest

257 et. Al, 2006).

\section{The Dounreay social value timeline}

259 Dounreay is one site of the NDA's wider estate. It is situated in a rural community with the

260 nuclear work playing a significant role in the lives of the district. The area was initially chosen

261 for nuclear energy development due to the remote location, but also because the local

262 community was declining in the 1950 s and so the siting of the experimental nuclear facility

263 was seen by politicians in Westminster as a means of creating a new lease of life for the

264 locality. As nuclear energy is being decommissioned in the area the NDA are managing a

265 sustainable transition to site closure.

266 There have been drivers and demands created by stakeholder input from both locally and

267 nationally (as shown in Table 3). Change of mission due to higher-level organisational

268 changes impacted progress, causing Dounreay to pass through three phases of social value

269 focus aligned with changing priorities. As the interacting local and national stakeholders

270 negotiated these changing priorities, shaping the social implications, local communities and

271 interested groups have been given opportunities to contribute through development of

272 practices such as Site Stakeholder Group meetings of community representatives. 
273 The story of the social value success of failure has been defined by different criteria,

274 developed and changed over time. With three main phases being seen in the changing

275 environment over time, as outlined in Table 3, it is also worth considering how the

276 opportunities for success and failure differ from the local to national perspective, that is to

277 say stakeholders in different places will make sense of the impacts differently.

278 INSERT TABLE 3

279 Phase 1. New nuclear: excitement of building a new society

280 The building of a nuclear site is reflected on by all participants as a positive thing for the

281 area: there was a decline of the agricultural and fishing industries, so the prospect of new

282 jobs was appreciated. But participants also spoke favourably about the legacy they felt it

283 brought; attracting a "cosmopolitan" society with the influx of scientists and many pastimes

284 they brought with them, and also the international scientific impact, which was reflected in

285 the document data.

286 Phase 2. Nuclear shut down: showing resilience through changing times

287 A chemical explosion in 1977 caused damage on site and the first radioactive particles are

288 detected in the environment, adding to growing mistrust of nuclear energy before the

289 Chernobyl accident in 1986. This led to a turnaround on a planning decision in 1986 to build

290 new reprocessing plants, as in 1988 the UK Government then announced a phased end to

291 research and development at Dounreay. This aligned with the Government's decision to

292 privatise energy in the 1990s, halting all nuclear build.

293 Without a clear mission of what decommissioning meant for site-end state many employees

294 were unsure of their future, still hoping for jobs for life.

295 Phase 3. Site mission to decommission: planning for alternative industries and investing in the 296 future 
297 This phase slowly emerged, responding to planning uncertainties on the site as

298 decommissioning as a goal was refined. A 60-year decommissioning plan was introduced in

2992000 costing $£ 4.3$ billion, but after the NDA was established in 2005 a review was

300 undertaken in 2007 bringing decommissioning targets brought forwards to 2032 at a

301 reduced cost of $£ 2.9 \mathrm{billion}$. A senior member of staff labelled this phase as the "mission to

302 solely turn the site into waste". This change in mission was in response to pressures from

303 central government but also driven by the aims within Dounreay organisational structure,

304 both of which were driven by external pressures felt after sever warning from the Health and

305 Safety Executive.

306 Influencing success and failure: stakeholder dynamism demonstrated with

307 changing characteristics and priorities

308 To examine the dynamics of Dounreay stakeholders a fragmented history of Dounreay and

309 its shifting contexts has been explored and outlined using three example stakeholder groups.

310 Framing patterns from the data chronologically demonstrated that as the overarching theme

311 of Dounreay changes the key stakeholders change - both those creating and influencing the

312 circumstances for success, but also those who will be most affected and how they respond.

313 The authors have codified the data thematically to identify how key stakeholders have

314 transformed over time, sometimes as completely new groups, but fulfilling similar roles as

315 previously.

316 Stakeholders can be both contributing and affected, or simply one, depending on how they

317 interact with Dounreay. For example, a stakeholder could potentially fall into two different

318 groups with differing needs and influence. One participant who worked on site as a previous

319 union representative was also active in local politics with the Scottish Green Party who are

320 anti-nuclear energy in all its forms. These two identities can clash with each other, as nuclear

321 energy is seen as both a friend and foe depending on which "hat" the participant is wearing. 
322 Frameworks that neatly categorise the identities of individual stakeholders fall short of

323 accounting for these intrinsic struggles.

324 Not only do the characteristics and structure of the stakeholder groups change, but also their 325 priorities and needs. This is how the goals and targets for success and failure move.

326 This paper does not aim to outline all stakeholders involved, but has identified 3 to

327 demonstrate the complexities of stories, characteristics and priorities changing:

- Regulators: currently Office for Nuclear Regulation (ONR)

- Site owner: currently the NDA, how has it changed over decades

- Local community

331 The stakeholder groups were chosen due to the richness with which they featured in the

332 case study data collection. The simplified timelines presented below were derived from the

333 multiple data sources and unpacked to make sense of the complexity of stakeholders

334 contained within Dounreay's history. The data is presented simultaneously descriptively to

335 present a clear story, and interpretatively as the author makes connections between the

336 various data sources to understand the influence of changing context on stakeholder

337 characteristics shifting.

338 Regulating 'safe and secure': industry learning and target setting

339 In the rush to embrace new energy possibilities, environmental safety was not fully

340 understood: it was only after operation that the safety implications shaped the industry. and

341 in more recent years the balance of stringent environmental regulation is being compared to

342 other sustainable value factors. The primary regulatory bodies have focused on the

343 environmental safety, in terms of radiation, health and safety on site, pollution and nuclear

344 safety. 
345 The guidelines and targets for environmental safety have changed considerably over the

346 decades. Following a major incident on the Windscale (now Sellafield) site in 1957 the

347 Nuclear Installations (Licensing and Insurance) Act 1959 established the Nuclear Safety

348 Division as the Inspectorate of Nuclear Installations within the Ministry of Power following a

349 recommendation from the UK Atomic Energy Authority (UKAEA) for a body to oversee

350 licencing new sites. Following the transfer of the Nuclear Safety Division to the Ministry of

351 Technology in 1968 it changed its title to Nuclear Installations Inspectorate (on

352 recommendation of the Nuclear Installations Act, 1965). This landscape has changed

353 significantly since then with all parties involved now operating in a new form.

354 Major changes happened at Dounreay when a series of safety incidents triggered an audit. A

355 decade after ceasing operation, but without a clear mission for the site, the safety audit

356 provided the guidance needed to strengthen the quality of work happening on site and set

357 targets for decommissioning and remediation.

"To a degree it was also the straw that broke the camel's back... when this happened management of the site" - D04 Site manager

361 In the review of the nuclear regulatory system (Stone 2008) there were many observations 362 made of the effectiveness of the industry. The most urgent issue identified was the lack of 363 skilled staff suitable for the Nuclear Inspector roles: it was difficult to retain staff due to 364 salary restrictions working in a public organisation, which was part of the reason for it 365 becoming a Public Corporation in 2014 after the 2013 Energy Act (Department of Energy and 366 Climate Change 2013). Several other recommendations were made for a more reliable 367 regulator: to restructure the organisation, and to create a single nuclear regulator for safety, 368 security and environment (previously HSE, EA and the Dangerous Goods Division of the 
369 Department for Transport). The umbrella organisation became the Office for Nuclear

370 Regulation formed as an agency of HSE. give people reassurance." - D01 Environmental specialist

373 All stakeholder groups benefit from this strategic relationship between the site and

374 regulator, as the reassurance of the safety and security from a somewhat feared technology.

375 This regulation helps provide a sense of reliability beyond what is expected from many other

376 contentious industries. However, it is of interest to note, the focus on "safe and secure" in

377 dialogue with stakeholders has been highlighted as an issue. Both in keeping the focus on

378 more negative aspects of nuclear energy, and by using technical-heavy language to convey

379 robustness which may be inaccessible to many, having the effect of many stakeholders not

380 understanding the safety and security measures in place.

\section{Following which leader? The shifting of responsibility and priorities}

382 UKAEA (UK Atomic Energy Agency) was established under Government ownership in 1954 to

383 do nuclear research and development for the burgeoning UK nuclear industry, with

384 Dounreay the centre for fast breeder technology. UKAEA's role changed significantly as the

385 Science and Technology Act 1965 broadened their work beyond atomic energy research.

386 The UKAEA divided itself into 3 business groups, preparing 2 for sale and privatisation. This

387 left a split of staff onsite, with the Government Division responsible for decommissioning

388 installations, but with much of the technical skill needed lost in redundancies (Health and

389 Safety Executive 1998).

“There wasn't a clear strategy. It was "OK, you don't want us to do this, what do you want us to do next?" So there was a real hiatus.......And then within that, you had this idea that one of the solutions was OK we set up all these units. Off you each go away and try and win business, and try and sustain. And some teams worked together, 

was set up as a private organisation which was still present on site. We had this huge antithesis between AEAT and the sort of UKAEA people" - D04 Site manager

397 Previous to the changes in 1980s, British Nuclear Fuels Ltd (BNFL) had been created as a split

398 of activities in UKAEA in 1971 for nuclear production to be managed separately. Later

399 becoming a public limited company owned by the UK Government, this created potential for

400 a business focus and encouraged technology spin offs. Further commercial parts of the

401 UKAEA were separated in 1995 to create Atomic Energy Authority Technology (AEAT).

402 AEAT later went on to be re-merged with UKAEA, and eventually UKAEA and BNFL merged to 403 form the NDA in 2005 after Government White Paper recommendations in 2003 led to the 4042004 Energy Act establishing the organisation to bring the works together.

405 Commercial arms continued with several restructures and buyouts, under names such as 406 British Nuclear Group (BNG), Westinghouse, Nexia Solutions and Nuclear Sciences and 407 Technology Services (NSTS). These organisations do not now directly interact with Dounreay 408 from the NDA perspective, but this complex shuffling of operations and ownership reflects 409 well the changing "singular" stakeholder that is responsible for directing Dounreay work 410 priorities. Dounreay has consistently responded to the calls for change as they put in place 411 what the influential stakeholders requested: as government changed tactics, this was 412 implemented on the ground and encouraged through site "mission".

413 The creation of the NDA in 2005 established a clear industry mission: "Our mission remains absolutely unchanged - to clean up the legacy from the UK's earliest nuclear sites, safely, securely and with care for people and the environment" - NDA Business Plan 2019-2022 
417 And this is in stark contrast to the origins of Dounreay. Beginning as a Government project,

418 pushed by Westminster, this was a nationally critical infrastructure project - as a matter of

419 national safety and security.

"UKAEA built a lot of houses in Thurso, a school, new high school, technical college, hospital facilities" - D04 Site manager

422 The predecessor of NDA was involved in the active building of society, but this now falls

423 beyond the remit of NDA's work. There are still expectations of some stakeholders that this

424 is NDA's responsibility and there has been a difficult change in mindset in how these services

425 are provided.

426 Shifting identities: Who is the "local community"? isolated community of $2 \frac{1}{2}$ thousand people, where do you meet your life partner? At the village dance. So everybody was related to everybody. You grew up surrounded by aunties, uncles,... Now when Dounreay came you'd this mass import of incomers. Now, obviously Atomics married locals and locals married Atomics, and it all became quite a mix. By the time I came it was much more difficult to work out who was who."

434 At the conception of nuclear energy at Dounreay, the community was in decline. The 435 shrinking agriculture and fishing industries, particularly during the wars, meant that people 436 were moving south to bigger cities with more employment opportunities. This was partly 437 why Dounreay was chosen to locate the new, untested and unsure, nuclear energy 438 technology that emerged from the Government weapons programme in World War II at 439 Windscale (Sellafield). 
440 New industry, and on such a large scale, meant the necessary influx of employees. Leading

441 scientists and engineers, with their families, moved from all over the UK, and quickly became

442 known as "the Atomics". The interesting thing is how over the years these people stayed and

443 become the local community. Now, decades later, those 'atomics' view new incomers with

444 suspicion. This is even more noticeable with the American employees who come to work on-

445 site temporarily as part of the Cavendish Dounreay Partnership (of UK owned Cavendish

446 Nuclear Ltd, US headquartered Jacobs Engineering Group, and American-owned AECOM)

447 which emerged as part of the new site management structure. It was mentioned through

448 participant interviews and during SSG observations that these American-incomers made no

449 attempt to integrate with the community, creating a sense of distrust.

"So it's more cosmopolitan in Thurso because, myself included, when I moved up I wanted to be nearer to Doureay than other towns. And I think that's what's happened with other people. They live up in other parts of the country....not so many people that work at Dounreay that live in Wick. They haven't had many infiltrations, or whatever the word that the locals use. I got called an 'incomer' recently, and I thought I've been here 14 years. The joke is unless you've got two generations in the

457 The changing idea of who should be included as the "local community" creates challenges

458 around how to define "successful" decommissioning and the social value or impact of the

459 work. The stories emerging of changing identities over the previous decades, and who is

460 included in stakeholder plans, points towards uncertainty in future decades of

461 decommissioning work and "local communities"

\section{The ever-changing stakeholder}

463 These examples of three stakeholder groups show that the stakeholder characteristics and 464 their perceptions and requirements have changed over the decades, in turn highlighting the 
465 challenges and complexities of holding down who and what matters in achieving social value

466 outcomes in a megaproject setting. Existing literature does not adequately grasp the

467 possibilities of the plurality of stakeholders when discussing stakeholder management, even

468 though some scholars like Bourne and Walker $(2005 ; 2006)$ and Walker et al. (2008) have

469 long called for a need to provide a more nuanced picture of the scale, scope and depth of

470 influence of multiple stakeholder groups. Our analysis of the ever-changing stakeholder

471 management dynamics over time throws up two key concerns. Firstly, stakeholders come

472 and go, or emerge as important and less important over time. As some fall out and others

473 emerge as influential, this would alter what is regarded as valuable by those affected by the

474 project. Thus, we add to a growing body of literature that shows that project success is not a

475 fixed entity but that success is only success in the current time and space (e.g. Davis, 2014;

476 2016). Second, a stakeholder can also intrinsically change in character, shifting their position.

477 Thus, change also where a stakeholder changes their own position over time (which is very

478 plausible in a megaproject). Additional complexity is added to megaprojects when

479 considering that many stakeholders may individually hold several positions at once - for

480 example, an employee on site is also part of the local community. These stakeholders may

481 have conflicting positions at the same time, bringing their bias to the project and affecting

482 decisions made.

483 This paper aimed to investigate how the appreciation of stakeholders' perceptions on

484 success and failure can lead to more productive processes in stakeholder engagement,

485 whether through integration or fragmentation particularly in the challenge of megaproject

486 decommissioning (Mulholland et al., 2019).

487 Changes to what constitutes 'success' happen regularly as organisations iteratively define

488 the overall design and planning end goals that are influenced by and in turn influences the

489 identification of the relevant stakeholder groups. The power and influence of stakeholders 
490 change over time as notions of 'success' or 'failure' become clearer. Thus, stakeholder

491 groups emerge as design and planning end goals become constructed, which in turn raises

492 new opportunities for other stakeholders to become involved.

493 Integration of these emerging stakeholders is difficult and the desire to integrate relevant

494 stakeholders is also questionable in larger, more complex projects since decommissioning

495 projects can span a long time and cross a vast space. Alternatively, Pitsis et al. (2004) suggest

496 integration is not essential for relationships, as fragmented parts can make up a whole. This

497 is not new thinking, with a 1969 government report suggesting that grouping all stakeholders

498 together for one labour solution did not offer to solve all the problems, even though some

499 statistics may show the benefit on productivity (Lewis 1969).

500 This empirical study also contributes to the ongoing conversation in defining what social

501 value means in practice (Cartigny \& Lord 2017; Raidén et al. 2019; Daniel \& Pasquire 2018),

502 including a wide array of stakeholders, beyond the common procurement focus (Cartigny \&

503 Lord 2018; Awuzie \& McDermott 2016; Loosemore 2015). It is by exploring the dynamic

504 nature of stakeholders that the conceptualisation of Social Value in practice has been

505 elevated - further explained in the final section as appreciating the balance between

506 needing anchor points for sense-making but in doing so taking a reductive approach to

507 complex stakeholder management (Brookes et al. 2017).

508 One limitation of this work is that all participants interviewed were local stakeholders to the

509 Dounreay site. However, in responses they spoke of both the local and national

510 environment of social value. These two levels of scale highlight an interesting question of

511 how social value outcomes vary between on-the-ground and higher level. This links with

512 Goldthau's (2014) work on the scales of investigating the sociotechnical relationships of

513 energy infrastructure governance but may have further implications in placing stakeholders

514 and their perspectives of social value on different scales. Thus far, Social Value studies have 
515 tended to focus on local stakeholders and value so this study raises questions around

516 adequate boundaries of measurement (discusses further in Mulholland et. al, 2019).

517 Recommended future work for this study would be to compare this to another case study to

518 allow for comparison if the idea of fragmentation always holds up for megaproject work. It

519 would be interesting to analyse the influence and impact of stakeholder groups further, to

520 demonstrate the usefulness and impact of fragmentation for social value outcomes.

\section{Closing remarks on using SROI for Social Value}

522 As stakeholders have been demonstrated to be ever-changing, this presents a challenge with

523 the first (and therefore all subsequent) steps of the SROI process. The impact of

524 identification and definition of stakeholders at the beginning of the SROI process will be seen

525 in the final reporting stage (seen in Table 1)- this shapes who the focus of the study is and

526 the resulting communication, a common problem with project sense-making (Clegg, 2016).

527 It is by figuring out the who, where and when of social value that we can begin to examine

528 the more detailed social value outcomes of megaprojects and how they are best

529 communicated. Applying any approach for social value, particularly the more detailed SROI

530 approach, brings difficulty in applying a coherent approach across the whole timescale and

531 locations of a complex project raising boundary questions: For who? When? Where? For how

532 long? Therefore, Social Value measurement and reporting can be viewed as only an island of

533 stability in a sea of change (Brookes et al. 2017). The ever-changing stakeholder lives in an

534 ever-changing world, exacerbated by the non-permanent nature of projects. However, with

535 such long timescales in megaprojects, utilising islands of stability allows sense-checking to

536 occur.

537 Social value is both a process and an entity, it can utilised as a verb or a noun (Bakken \&

538 Hernes 2006). The process is an attempt to create islands of stability. Attempting to

539 categorically measure and define the social value of a megaproject simplifies the complexity, 
540 not telling the whole picture, but it creating signposts for an interaction between static and

541 dynamic identities.

542 With the growing concern for social value in infrastructure (Cartigny \& Lord 2017; Daniel \&

543 Pasquire 2018) and the reported high likeliness of megaproject failure (Flyvbjerg 2014) the

544 engineering community needs to move forwards with finding ways to report on the social

545 impact of their work, particularly for publicly funded projects. SROI offers one method to do

546 this.

547 However, the limitations of SROI have been acknowledged (Watson et al. 2016) and have yet

548 to be applied in a robust, systematic way in larger more complex contexts. This paper

549 outlines the challenges that will be faced by the engineering community in embracing the

550 methodology, but also the potential opportunities. SROI needs further investigation in

551 infrastructure and general megaproject case studies to unpack the opportunities of focusing

552 on the stakeholders and boundaries in creating meaningful SROI reports.

553 References

554 Aaltonen, K. and Kujala, J. (2010) A project lifecycle perspective on stakeholder influence

555 strategies in global projects, Scandinavian Journal of Management, 25(4), 381-397.

556 Aaltonen, K. et al., 2015. Stakeholder Dynamics During the Project Front-End: The Case of

$557 \quad$ Nuclear Waste Repository Projects. Project Management Journal, 7(3), pp.47-67.

558 Ackermann, F. \& Eden, C., 2011. Strategic Management of Stakeholders: Theory and Practice.

559 Long Range Planning, 44(3), pp.179-196. Available at:

$560 \quad$ http://dx.doi.org/10.1016/j.Irp.2010.08.001.

561 Anon, 2012. Public Services (Social Value) Act 2012, Parliament of the United Kingdom.

562 Atkinson, R., 1999. Project management: cost, time and quality, two best guesses and a

563 phenomenon, its time to accept other success criteria. International Journal of Project 
565

566

567

568

Awuzie, B.O. \& McDermott, P., 2016. The role of contracting strategies in social value implementation. Proceedings of the Institution of Civil Engineers - Management, Procurement and Law, 169(3), pp.106-114. Available at: http://www.icevirtuallibrary.com/doi/10.1680/jmapl.15.00024.

Bakken, T. \& Hernes, T., 2006. Organizing is both a verb and a noun: Weick meets whitehead. Organization Studies, 27(11), pp.1599-1616.

Bourne, L. and Walker, D. H. T. (2005) Visualising and mapping stakeholder influence, Management Decision, 43(5), 649-660.

Bourne, L. and Walker, D. H. T. (2006) Visualizing stakeholder influence - Two Australian examples, Project Management Journal, 37(1), 5-21.

Braun, V. and Clarke, V. (2006) Using thematic analysis in psychology, Qualitative Research in Psychology, 3 (2). pp. 77-101. ISSN 1478-0887

Brookes, N. et al., 2017. An island of constancy in a sea of change: Rethinking project temporalities with long-term megaprojects. International Journal of Project Management, 35(7), pp.1213-1224. Available at: http://dx.doi.org/10.1016/j.ijproman.2017.05.007.

Cabinet Office, 2015. Social Value Act Review, London. Available at: http://www.navca.org.uk/social-value-bill.

Caldas, C. \& Gupta, A., 2016. Critical factors impacting the performance of mega-projects. Engineering, Construction and Architectural Management, 24(6), pp.920-934.

Cartigny, T. \& Lord, W., 2017. Defining social value in the UK construction industry. Proceedings of the Institution of Civil Engineers - Management, Procurement and Law, 
588 Cartigny, T. \& Lord, W., 2018. Evaluating social value in the UK construction industry. Proceedings of the Institution of Civil Engineers - Management, Procurement and Law, 172(1), pp.8-16.

591

Chan, P.W., 2016. Expert knowledge in the making: using a processual lens to examine expertise in construction. Construction Management and Economics, 34(7-8), pp.471483. Available at: http://dx.doi.org/10.1080/01446193.2016.1190851.

Clegg, S.R. et al., 2016. Power and sensemaking in megaprojects. In B. Flyvbjerg, ed. The Oxford Handbook of Megaproject Management. Oxford: Oxford University Press, pp. 121.

Courpasson, D., Dany, F. \& Clegg, S., 2011. Resisters at Work: Generating Productive Resistance In The Workplace. Organization Science, 23(3), pp.801-819.

Daniel, E. \& Pasquire, C., 2018. Creating Social Value within the Delivery of Construction Projects. Engineering, Construction and Architectural Management.

Daniel, E. \& Pasquire, C., 2017. Social Value Evidencing Toolkit ( SVET ): A framework for social delivery on Highways England infrastructure schemes, Nottingham: Nottingham Trent University Publications.

Davis, K., 2016. A method to measure success dimensions relating to individual stakeholder groups. International Journal of Project Management, 34(3), pp.480-493. Available at: http://dx.doi.org/10.1016/j.ijproman.2015.12.009.

Davis, K., 2014. Different stakeholder groups and their perceptions of project success. International Journal of Project Management, 32(2), pp.189-201. Available at: http://dx.doi.org/10.1016/j.ijproman.2013.02.006. 
610 Department of Energy and Climate Change, 2013. Energy Act, Available at: http://www.legislation.gov.uk/ukpga/2013/32/pdfs/ukpga_20130032_en.pdf.

612 Engwall, M., 2003. No project is an island: Linking projects to history and context. Research

Eriksson, P.E. et al., 2014. Managing short-term efficiency and long-term development

Eskerod, P., Huemann, M. \& Savage, G., 2015. Project Stakeholder Management- Past and

Freeman, R.E., 1984. Strategic management: a stakeholder approach [2010 Reis., Cambridge: Cambridge Unviersity Press. Available at: http://copac.jisc.ac.uk/search?title=Strategic https://www.researchgate.net/publication/265568763_A_Report_From_the_Good_Shi 
Goldthau, A., 2014. Rethinking the governance of energy infrastructure: Scale, decentralization and polycentrism. Energy Research and Social Science, 1, pp.134-140. Available at: http://dx.doi.org/10.1016/j.erss.2014.02.009. experiment with data saturation and variability, Field Methods, 18(1), 59-82.

639 Health and Safety Executive, 1998. Safety Audit of Dounreay. at: http://www.legislation.gov.uk/ukpga/1965/57/pdfs/ukpga_19650057_en.pdf. decommissioning industry: a responsible approach towards better performance.

Jepsen, A.L. \& Eskerod, P., 2009. Stakeholder analysis in projects: Challenges in using current guidelines in the real world. International Journal of Project Management, 27(4), pp.335-343. Available at: http://dx.doi.org/10.1016/j.ijproman.2008.04.002. Journal, 14(4), pp.19-24.

650 Kornberger, M., Clegg, S.R. \& Carter, C., 2006. Rethinking the polyphonic organization: Managing as discursive practice. Scandinavian Journal of Management, 22(1), pp.3-30.

652 Lewis, R., 1969. Report of the Phelps Brown Committee. The Modern Law Review, 32(1), pp. $75-80$.

654 Locatelli, G., Mancini, M. \& Romano, E., 2014. Systems Engineering to improve the 655 governance in complex project environments. International Journal of Project 

http://dx.doi.org/10.1016/j.ijproman.2013.10.007.

Loosemore, M., 2015. Social procurement in UK construction projects. International Journal of Project Management, 34(2), pp.133-144. Available at: http://dx.doi.org/10.1016/j.ijproman.2015.10.005 [Accessed October 6, 2016].

Ma, H. et al., 2017. The societal governance of megaproject social responsibility. International Journal of Project Management, 35(7), pp.1365-1377. Available at:

Mišić, S. \& Radujković, M., 2015. Critical Drivers of Megaprojects Success and Failure. Procedia Engineering, 122(ORSDCE), pp.71-80.

Mitchell, R., Agle, B. and Wood, D. 1997. Toward a Theory of Stakeholder Identification and value: case studies in UK nuclear decommissioning. Journal of Cleaner Production. studies of supply chain management? A review and research agenda. Supply Chain 
Management: An International Journal, 22(6), pp.522-541. Available at: http://www.emeraldinsight.com/doi/10.1108/SCM-12-2016-0436.

New Economics Foundation, 2007. Measuring Real Value: a DIY guide to Social Return on Investment, London. Available at: https://neweconomics.org/2007/05/measuring-realvalue.

Nicholls, J., 2016. Social return on investment-Development and convergence. Evaluation and Program Planning, 64(October), pp.127-135. Available at: http://linkinghub.elsevier.com/retrieve/pii/S0149718916302361.

Ninan, J. \& Mahalingam, A., 2017. Stakeholder Management Strategies in Infrastructure Megaprojects - A Dimensions of Power Perspective. Engineering Project Organization

Nuclear Decommissioning Authority, 2016. Nuclear Decommissioning Authority Annual

Olander, S., 2007. Stakeholder impact analysis in construction project management. Interorganizational Collaboration. M@n@agement, 7(3), pp.60-69. Available at: Power, M. (1997) The Audit Society: Rituals of verification. Oxford: Oxford University Press. Raidén, A. et al., 2019. Social value in construction 1st ed., London: Routledge. 
704 Sánchez, M.A., 2015. Integrating sustainability issues into project management. Journal of

705 Cleaner Production, 96(June), pp.319-330. Available at:

$706 \quad$ http://dx.doi.org/10.1016/j.jclepro.2013.12.087.

707 Savage, G.T. et al., 1991. Strategies for assessing and managing organizational stakeholders.

$708 \quad$ Academy of Management Executive, 5(2)(2), pp.61-75.

709 Secretary of State for Trade and Industry, 2002. Managing the nuclear legacy: a strategy for $710 \quad$ action (White Paper), London.

711 Shenhar, A. \& Holzmann, V., 2017. The Three Secrets of Megaproject Success : Clear

712 Strategic Vision, Total Alignment, and Adapting to Complexity. Project Management

713 Journal, 48(6), pp.29-46.

714 Sherrouse, B.C., Clement, J.M. \& Semmens, D.J., 2011. A GIS application for assessing,

715 mapping, and quantifying the social values of ecosystem services. Applied Geography,

$716 \quad 31(2)$, pp.748-760.

717 Shore, C. and Wright, S. (2015) Governing by numbers: Audit culture, rankings and the new $718 \quad$ world order. Social Anthropology, 23(1), 22-28.

719 Spradley, J.P., 1979. The Ethnographic Interview, New York: Holt, Rinehart and Winston.

720 Stone, T., 2008. Nuclear Regulatory Review Private Advice and Reasoning Observations by

721 Tim Stone for the Secretary of State for Energy and Climate Change,

722 The Roberts Enterprise Development Fund, 2001. SROI Methodology: Analyzing the Value of 723 Social Purpose Enterprise Within a Social Return on Investment Framework. Available 724 at: https://redfworkshop.org/wp-content/uploads/2017/06/SROI-Methodology725 2001.pdf.

726 Turkulainen, V., Aaltonen, K. \& Lohikoski, P., 2015. Managing Project Stakeholder 
728 Walker, D. H. T., Bourne, L. M. and Shelley, A. (2008) Influence, stakeholder mapping and visualization, Construction Management and Economics, 26(6), 645-658.

730 Watson, K.J. et al., 2016. Capturing the social value of buildings: The promise of Social Return on Investment (SROI). Building and Environment, 103, pp.289-301. Available at: http://www.sciencedirect.com/science/article/pii/S0360132316301214 [Accessed October 6, 2016].

Watson, K.J. \& Whitley, T., 2017. Applying Social Return on Investment (SROI) to the built environment. Building Research \& Information, 45(8), pp.875-891. Available at: https://www.tandfonline.com/doi/full/10.1080/09613218.2016.1223486. Study of an Algerian Megaproject. Procedia Computer Science, 64(1877), pp.844-851. Available at: http://dx.doi.org/10.1016/j.procs.2015.08.637. 